\title{
SINDROME ANTISINTETASA EN TIEMPO DE PANDEMIA
}

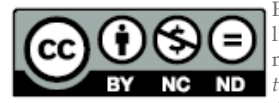

Este artículo está bajo una Este articulo esta bajo una mons de tipo Reconocimiento - No comercial - Sin obras
derivadas 4.0 International. OPEN ACCESS

1. Universidad Central del Ecuador. Facultad de Ciencias Médicas. Posgrado de Neumología. Quito, Ecuador.

2. Hospital de Especialidades Carlos Andrade Marín. Médico en funciones hospitalarias. Quito, Ecuador

\section{ORCID ID:}

Aguilar Carlos Luis

orcid.org/0000-0001-5816-0849

Cuenca Andrés Vinicio

orcid.org/0000-0002-3889-9520

* Corresponding author:

Aguilar Carlos Luis

E-mail: carlitos_doc91@hotmail.com

Article history: Manuscript presented at the I Clinical Case Contest - Hospital Vozandes Quito, February 27, 2021.

CARE 2017 Check List statement: The authors have real the CARE 2017 Check List and the manuscript was prepared and revised according to the CARE 2017 Checklist.

Conflict of interest: All authors declared that there are no conflicts of interest.

Financial disclosure: The authors have no financial relationships relevant to this article to disclose.

Forma de citar este artículo: Aguilar CL, Cuenca AV. SINDROME ANTISINTETASA EN TIEMPO DE PANDEMIA. Rev Med Vozandes. 2021; 32 (1 Suppl 1): S25-S26

\section{Resumen}

Introducción: El Síndrome Antisintetasa es una entidad poco frecuente que se la incluye dentro de las miopatías inflamatorias idiopáticas, caracterizada por la presencia de anticuerpos antisintetasa, los mismos se pueden encontrar en $39.1 \%$ de los pacientes con dichas miopatías. La afectación es sistémica siendo las principales a nivel articular en un $40 \%-80 \%$. El daño pulmonar se da en un $60 \%-80 \%$ siendo los hallazgos más frecuentes el vidrio esmerilado, reticulación de predominio en segmentos inferiores probablemente con un patrón de neumonía intersticial no específica, neumonía organizada o patrones mixtos. En cuanto a la afectación muscular se produce en un 60\%$80 \%$. El tratamiento se basa en uso de corticoides, inmunosupresores y agentes biológicos.

Descripción del Caso: Se aborda a una paciente femenina de 38 años de edad sin antecedentes clínicos ni familiares de importancia, soltera (no hijos), que presentó de manera paulatina e intermitente dolor articular y debilidad muscular asociados a disnea progresiva, en el contexto de la pandemia actual se realizó hisopado para SARSCOV-2 por 2 ocasiones así como anticuerpos para el mismo virus siendo negativos, con hallazgos tomográficos compatible con un patrón alternativo, a pesar de lo mencionado se trató de manera particular con un esquema dirigido hacia COVID-19, con resolución parcial de la sintomatología y posterior exacerbación de la misma, por lo que acude a atención hospitalaria, donde se repite hisopado obteniendo negatividad del mismo, decidiendo en esta ocasión valoración por el Servicio de Neumología y hospitalización.

Durante su estadía se realizó panel inmunológico donde se evidencia elevación débil de factor reumatoide, debido a cuestiones de logísticas panel de Miositis nos encontramos a la espera, sin embargo ante la falta de etiología específica se decide realizar biopsia pulmonar reportando un patrón de neumonía organizada concordante con el diagnostico tomográfico, la evolución de la paciente fue favorable con un tratamiento de soporte hasta que se recibió los resultados de panel inmunológico externo evidenciándose una elevación marcada del anticuerpo anti-Jo, sumado a las manifestaciones clínicas y de imagen se cataloga el cuadro como un Síndrome Antisintetasa.

De esta manera con apoyo de reumatología se inicia tratamiento con corticoide (metilprednisolona), inmunosupresores (micofenolato) y agente biológico (rituximab); con lo cual hubo mejoría clínica importante, disminución de soporte de 02 así como de lesiones pulmonares, con lo que se procedió al alta con el seguimiento respectivo por parte de los servicios involucrados.

Conclusión: Como evidenciamos en el caso clínico ya de una manera retrospectiva podemos aseverar que cumplía con las manifestaciones clínicas de la enfermedad, si bien nos encontramos cursando una pandemia donde la afectación pulmonar es ponderante una vez descartada la misma se debe abordar otras posibilidades diagnosticas que como en la paciente culmino con la presentación de un cuadro reumatológico con daño pulmonar.

Palabras clave: Síndrome Antisintetasa, Enfermedades Intersticiales, Anticuerpo anti Jo 1, Miositis. 


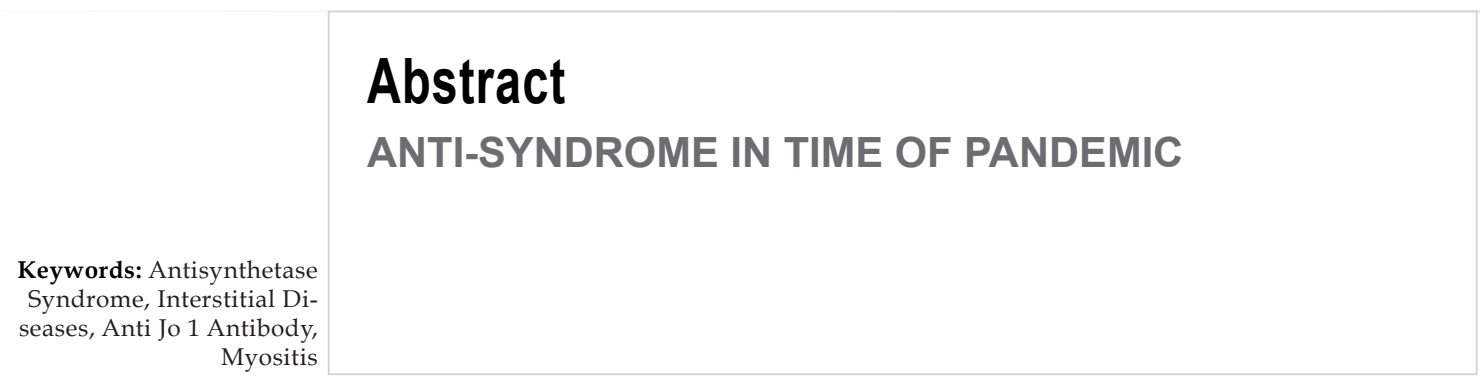

Introduction: The Antisynthetase Syndrome is a rare entity that is included within the idiopathic inflammatory myopathies, characterized by the presence of antisynthetase antibodies, they can be found in $39.1 \%$ of the patients with these myopathies. The affectation is systemic being the main ones at the articular level in $40 \%-80 \%$. Lung damage occurs in $60 \%-80 \%$, the most frequent findings being ground glass, predominantly crosslinking in lower segments, probably with a pattern of non-specific interstitial pneumonia, organized pneumonia, or mixed patterns. Regarding muscle involvement, it occurs in $60 \%-80 \%$. Treatment is based on the use of corticosteroids, immunosuppressants, and biological agents.

Case description: A 38-year-old female patient with no significant clinical or family history was approached, single (no children), who presented gradual and intermittent joint pain and muscle weakness associated with progressive dyspnea, in the context of The current pandemic was swabbed for SARS-COV-2 on two occasions as well as antibodies for the same virus being negative, with tomographic findings compatible with an alternative pattern, despite the aforementioned, it was treated in a particular way with a scheme directed towards COVID -19, with partial resolution of the symptoms and subsequent exacerbation of the same, for which he went to hospital care, where the swab was repeated obtaining negativity of the same, deciding on this occasion an evaluation by the Pneumology Service and hospitalization.

During his stay, an immunological panel was performed where a weak elevation of rheumatoid factor is evidenced, due to logistical issues Myositis panel we are waiting, however, due to the lack of specific etiology, it was decided to perform a lung biopsy reporting a concordant pattern of organized pneumonia With the tomographic diagnosis, the evolution of the patient was favorable with supportive treatment until the results of the external immunological panel were received, evidencing a marked elevation of the anti-Jo antibody, added to the clinical and image manifestations, the picture is cataloged as an Antisynthetase Syndrome.

Thus, with the support of rheumatology, treatment with corticosteroids (methylprednisolone), immunosuppressants (mycophenolate) and biological agent (rituximab) is started; with which there was significant clinical improvement, decrease in $\mathrm{O} 2$ support as well as lung lesions, with which we proceeded to discharge with the respective follow-up by the services involved.

Conclusion: As we evidenced in the clinical case, in a retrospective way, we can assert that it complied with the clinical manifestations of the disease, although we are experiencing a pandemic where lung involvement is important, once it has been ruled out, other diagnostic possibilities must be addressed. As in the patient, it culminated in the presentation of a rheumatological picture with lung damage. 